\title{
QUANTITATIVE IDENTIFICATION OF CONSTRUCTION RISK
}

\author{
KASPROWICZ T. ${ }^{1}$
}

\begin{abstract}
Risks pertaining to construction work relate to situations in which various events may randomly change the duration and cost of the project or worsen its quality. Because of possible significant changes of random events, favorable, moderate, and difficult conditions of construction work are considered. It is the first stage of the construction risk analysis. The probabilistic parameters of construction are identified and described by using the design characteristics model of the structure and the construction technology model. The first describes the probabilistic properties of the structure execution's technology. The second describes the probabilistic properties of the works execution. Both models contain basic probabilistic data for scheduling, cost estimating, and risk assessment of the construction.
\end{abstract}

Keywords: structure, construction, models, identification of the construction risk

\section{INTRODUCTION}

Construction projects ${ }^{2}$ are realized in a specific life cycle. The main stage of this cycle is execution of the works on a construction site. This stage is called here "construction". The main goal of construction is the full completion of the facility in accordance with design documentation and technical specification of performance and acceptance of the work on schedule, within budget and safety. Detailed explanation of these problems can be found in publication [5]. In many situations,

\footnotetext{
${ }^{1}$ Prof. DSc., PhD., Eng., Military University of Technology, Faculty of Civil Engineering and Geodesy, Kaliski Str. 2, 00 - 908 Warsaw, Poland, e-mail: tadeusz.kasprowicz@,wat.edu.pl

${ }^{2}$ Construction - the building of structures and facilities;

Construction works - an activity involving mental or physical effort done in order to build structures and facilities

Construction project - individual or collaborative activities planned and designed to build structures and facilities; Life cycle of construction project: planning phase, design phase, construction phase, operation phase;
} 
the schedule and cost of the construction should be estimated taking into consideration the influence of random factors. Experts are generally in agreement that the risk should be analyzed in the project's life cycle. Such approaches are presented for example in publication [1]. In the paper a reallife project database is created and risk analysis is based on Monte Carlo simulations. The approach to the identification of the project risk using PERT method rules has been presented in articles [2, 3]. Another approach to the risk analysis has been presented in paper [4]. The author has described the preparation of the Project Risk Assessment Methodology and its mitigation in complex construction projects. In publications $[6,7]$ the author shows in which way the risk factors that may disrupt the works can be denoted. A similar approach to the risk identification and assessment has been described in papers $[8,9]$. The authors of these publications have used the rules of the PERT method in order to identify and assess the risks associated with construction works. In all publications mentioned above two stages can be perceived. The first is identification of the type of construction risk. The second one is assessment of the construction risk. In the following article the first stage of construction risk analysis has been presented. It is the quantitative method of the construction risk identification. The method allows identification of the construction risk, which is caused by random events in the process of works execution on the construction site and its surroundings. The data which is gathered and described in this stage is used in the second stage of risk analysis, during the assessment of the risk of the delay of the final deadline and the risk of the total cost increase of the construction completion.

\section{RULES OF CONSTRUCTION RISK IDENTIFICATION}

Random events may accidentally disrupt execution and cause an extension of the duration of the project and exceeding its total cost. In highly unstable conditions of the construction, it is reasonable to consider moderate, favorable, and difficult conditions of construction completion and $l^{3}$, average $^{4}$ and high ${ }^{5}$ risk levels of its completion.

The moderate conditions of construction are analyzed in ordinary circumstances, when random events may have an average impact on the duration, cost, and quality of the works. In such situations, random events may cause ordinary technological, organizational, financial, and legal problems. However, they have inconsiderable influence on the safety of people, the use of machinery

\footnotetext{
${ }^{3}$ Low - below average in amount, extent, or intensity,

${ }^{4}$ Indifferent - neither good nor bad; mediocre; natural in respect of some specified physical property. Average - an amount, standard, level, or rate regarded as usual or ordinary:

${ }^{5}$ High - extending above the normal or average level,
} 
and equipment, and the operation of the contractor or the customer. However, always a set $\boldsymbol{U}$ of works $u_{j}$ should be executed by a set $\boldsymbol{H}$ of teams $\boldsymbol{H}_{j, r}$ in accordance with the design documentation and technical specifications of performance and acceptance of the works, and other technical and quality requirements. In the risk conditions the size $L_{j}$, duration $T_{j, r}$, and cost $K_{j, r}$, of the works $u_{j} \in \boldsymbol{U}$ when they are executed by teams $\boldsymbol{H}_{j, r} \in \boldsymbol{H}$ are random variables. At any given moment of works completion they may have the actual values $l_{j}, t_{j, r}$, and $k_{j, r}$. These values are unknown during the planning process. The values of the random variables $L_{j}, T_{j, r}$, and $K_{j, r}$, can be estimated similarly to the PERT method. Based on the design documentation and the analysis of execution conditions one can specify three possible values of $L_{j}$ : the rationally lowest, that is the minimum value $\underline{L}_{j}$, the realistic value $\hat{L}_{j}$, and reasonably the highest, that is the maximum value $\bar{L}_{j}$. The expected values $E\left[L_{j}\right]$ can be calculated as follows:

$$
E\left[L_{j}\right]=\frac{\underline{L}_{j}+4 \widehat{L}_{j}+\bar{L}_{j}}{6}
$$

In order to evaluate the expected values of the variables $T_{j, r}$ and $K_{j, r}$, at the beginning, the realistic values $\widehat{T}_{j, r}$ and $\widehat{K}_{j, r}$ are estimated. The duration $\widehat{T}_{j, r}$ can be calculated according to the formula $\widehat{T}_{j, r}=\widehat{L}_{j} \widehat{P}_{j, r}$. The realistic number $\widehat{P}_{j, r}$ of time units, which are necessary for the execution of each unit of works $u_{j} \in \boldsymbol{U}^{r} \subset \boldsymbol{U}$ by the team $\boldsymbol{H}^{r} \in \boldsymbol{H}$ can be determined on the basis of commonly used catalogs of standards of resource consumption. In most cases this approach fully corresponds to reality. If it is not true, the values $\widehat{T}_{j, r}$ and $\widehat{P}_{j, r}$ should be estimated directly on the basis on the individual analysis of the technology, resources, and conditions of construction. The costs $\widehat{K}_{j, r}$ can be calculated according to the formulas $\widehat{K}_{j, r}=\widehat{T}_{j, r} \widehat{\mathrm{K}}_{j, r}^{t}$ or $\widehat{K}_{j, r}=\widehat{L}_{j, r} \widehat{\mathrm{K}}_{j, r}^{l}$. The unit cost $\widehat{\mathrm{K}}_{j, r}^{t}$ (e.g. dollars per working hour) or $\widehat{\mathrm{K}}_{j, r}^{l}$ (e.g. dollars per cubic meter) which must be spent on the execution of the works $u_{j} \in \boldsymbol{U}^{r} \subset \boldsymbol{U}$ by team $\boldsymbol{H}^{r}$ can be estimated by using the commonly used price lists. In many situations they must be estimated on the basis of the individual analysis of the size and the nature of works, the economic conditions, and the construction industry market. Then, the 
values $\underline{T}_{j, r}, \bar{T}_{j, r}, \underline{K}_{j, r}$, and $\bar{K}_{j, r}$ can be calculated by using the formulas: $\underline{T}_{j, r}=\widehat{T}_{j, r}-\underline{p}_{j, r}^{t} \hat{T}_{j, r}$, $\bar{T}_{j, r}=\widehat{T}_{j, r}+\bar{p}_{j, r}^{t} \widehat{T}_{j, r}, \underline{K}_{j, r}=\widehat{K}_{j, r}-\underline{p}_{j, r}^{k} \widehat{K}_{j, r}$ and $\bar{K}_{j, r}=\widehat{K}_{j, r}+\bar{p}_{j, r}^{k} \widehat{K}_{j, r}$.

The coefficients of optimism $\underline{p}_{j, r}^{t}$ describe the possible shortening of works duration in moderate conditions because of possible better construction conditions and the likely weakening of the random events' impact on the course and results of the works. These coefficients can equal $\underline{p}_{j, r}^{t} \in[0,05,0,1,0,15,0,20]$. They should be considered separately for each work and the set of existing perturbations. The product $\underline{p}_{j, r}^{t} \widehat{T}_{j, r}$ points out the bottom endpoint of $T_{j, r}$ values. The coefficients of pessimism $\bar{p}_{j, r}^{t}$ describe the possible lengthening of project duration in moderate conditions and the likely strengthening of the random events' impact on the course and results of the work. These coefficients can equal $\bar{p}_{j, r}^{t} \in[0,1,0,15,0,20,0,25]$. The product $\bar{p}_{j, r}^{t} \widehat{T}_{j, r}$ points out the upper endpoint of $T_{j, r}$ values. Similarly, one can estimate the coefficients $\underline{p}_{j, r}^{k}$ and $\bar{p}_{j, r}^{k}$. The products $\underline{p}_{j, r}^{k} \hat{K}_{j, r}$ and $\bar{p}_{j, r}^{k} \hat{K}_{j, r}$ point out the bottom and upper endpoints. The expected durations $E\left[T_{j, r}\right]$ and the expected costs $E\left[K_{j, r}\right]$ of the works $u_{j} \in \boldsymbol{U}^{r}$ can be calculated as follows:

$$
E\left[T_{j, r}\right]=\frac{\underline{T}_{j, r}+4 \widehat{T}_{j, r}+\bar{T}_{j, r}}{6} \text { and } E\left[K_{j, r}\right]=\frac{\underline{K}_{j, r}+4 \widehat{K}_{j, r}+\bar{K}_{j, r}}{6}
$$

The standard deviation of duration $\sigma\left(T_{j, r}\right)$ and cost $\sigma\left(K_{j, r}\right)$ of works $u_{j} \in \boldsymbol{U}$ executed by executors $\boldsymbol{H}^{r} \in \boldsymbol{H}$ can be calculated by using the following formulas:

$$
\sigma\left(T_{j, r}\right)=\frac{\bar{T}_{j, r}-\underline{T}_{j, r}}{6} \text { and } \sigma\left(K_{j, r}\right)=\frac{\bar{K}_{j, r}-\underline{K}_{j, r}}{6}
$$

The favorable conditions of construction should be analyzed when it is likely that not all important random events that are probable in the moderate conditions may occur, or when they may be less severe and may have a weaker impact on the process of works execution and its results. These are the best conditions expected during construction. In this case, certain values $l_{j}$ and expected values $E\left[L_{j}\right]$ of the variables $L_{j}$ can be estimated in a way similar to the moderate conditions impacting 
construction. Based on the theoretical analysis and practical observations, it is then reasonable to assume that the realistic and the pessimistic values of the duration and the cost of works are equal to the values which have been estimated for the moderate conditions impacting construction, that is $\widehat{T}_{j, r}^{p}=\widehat{T}_{j, r}, \widehat{K}_{j, r}^{p}=\widehat{K}_{j, r}, \bar{T}_{j, r}^{p}=\bar{T}_{j, r}$, and $\bar{K}_{j, r}^{p}=\bar{K}_{j, r}$. The optimistic values $\underline{T}_{j, r}^{p}$ and $\underline{K}_{j, r}^{p}$ can be calculated according to the formulas $\underline{T}_{j, r}^{p}=\underline{T}_{j, r}-\underline{p}_{j, r}^{p t} \underline{T}_{j, r}$ and $\underline{K}_{j, r}^{p}=\underline{K}_{j, r}-\underline{p}_{j, r}^{p k} \underline{K}_{j, r}$. The coefficients of the conditions improvement $\underline{p}_{j, r}^{p t}$ and $\underline{p}_{j, r}^{p k}$ describe an additional possible shortening of duration and reduction of costs of the work due to the favorable construction conditions. They depend directly on the probable, particularly propitious changes of nature, place, time, and intensity of random events. The values $\underline{p}_{j, r}^{p k}$ depend additionally on the changes of the general financial conditions of the economy; possible unfavorable changes of labor costs, costs of machines and equipment, and costs of building components or materials. They can equal for example $[0,05,0,10,0,15]$. These coefficients $\underline{p}_{j, r}^{p t}$ and $\underline{p}_{j, r}^{p k}$ should be individually estimated for each works. Based on the values $\underline{T}_{j, r}^{p}, \widehat{T}_{j, r}^{p}, \bar{T}_{j, r}^{p}, \underline{K}_{j, r}^{p}, \widehat{K}_{j, r}^{p}$, and $\bar{K}_{j, r}^{p}$, one can calculate the expected duration $E\left[T_{j, r}^{p}\right]$, the expected cost $E\left[K_{j, r}^{p}\right]$, the standard deviation of duration $\sigma\left(T_{j, r}^{p}\right)$, and the standard deviation of costs $\sigma\left(K_{j, r}^{p}\right)$ by using the formulas similar to the ones used in the moderate risk conditions estimate (Eqs. 2, 3).

The difficult conditions of construction should be analyzed when it is likely that, aside from the random events that are probable in the moderate conditions, new critical random events may occur, or the already predicted random events may be more changeable or more severe and may have a stronger negative impact on project execution and works results. These are the worst possible conditions impacting works execution. In this case, certain values $l_{j}$ and the expected values $E\left[L_{j}\right]$ of the variables $L_{j}$ are estimated similarly to the assessment of the moderate conditions model. Based on the theoretical analysis and practical observations, it is reasonable to assume that the optimistic values $\underline{T}_{j, r}^{n}$ and $\underline{K}_{j, r}^{n}$, and the realistic values $\widehat{T}_{j, r}^{n}$ and $\widehat{K}_{j, r}^{n}$ are equal to the values that have been estimated for the moderate conditions, that is $\underline{T}_{j, r}^{n}=\underline{T}_{j, r}, \underline{K}_{j, r}^{n}=\underline{K}_{j, r}, \widehat{T}_{j, r}^{n}=\widehat{T}_{j, r}, \widehat{K}_{j, r}^{n}=\widehat{K}_{j, r}$. The pessimistic values $\bar{T}_{j, r}^{n}$ and $\bar{K}_{j, r}^{n}$ of the duration and the cost of the works can be calculated by using the formulas: $\bar{T}_{j, r}^{n}=\bar{T}_{j, r}+\bar{p}_{j, r}^{n t} \bar{T}_{j, r}$ and $\bar{K}_{j, r}^{n}=\bar{K}_{j, r}+\bar{p}_{j, r}^{n k} \bar{K}_{j, r}$. The coefficients of condition de- 
terioration $\bar{p}_{j, r}^{n t}$ and $\bar{p}_{j, r}^{n k}$ describe the additional possible prolongation of duration and increase of cost of the work due to the difficult conditions which could impact construction. Values $\bar{p}_{j, r}^{n k}$ depend additionally on the changes of the financial conditions in the construction industry market. They are, for example, $[0,10,0,15,0,20]$. Here, based on the values $\underline{T}_{j, r}^{n}, \underline{K}_{j, r}^{n}, \widehat{T}_{j, r}^{n}, \widehat{K}_{j, r}^{n}, \bar{T}_{j, r}^{n}$, and $\bar{K}_{j, r}^{n}$, one can calculate the expected duration $E\left[T_{j, r}^{n}\right]$, the expected cost $E\left[K_{j, r}^{n}\right]$, the standard deviation of duration $\sigma\left(T_{j, r}^{n}\right)$, and the standard deviation of cost $\sigma\left(K_{j, r}^{n}\right)$ by using the formulas similar to the ones applied in the moderate conditions of risk calculations (Eqs. 2, 3).

\section{MODELS OF CONSTRUCTION IN RISK CONDITIONS}

Two types of models are developed here. The first, the design characteristics model of structure $\boldsymbol{S}$, describes the type, size, technology, and permissible sequence of the work. In order to develop the model one should divide the structure into relatively independent elements, modules, or subsystems. On the basis of the division a set $\boldsymbol{U}$ of works $u_{j}$ is defined. Next, the values $l_{j}$ or expected values $E\left[L_{j}\right]$ of the amount of work $u_{j} \in \boldsymbol{U}$ should be estimated. Finally, the permissible sequence, size, and other limitations of works execution are described as follows:

$$
\boldsymbol{S}=\langle\boldsymbol{G}, \boldsymbol{L}\rangle
$$

$\boldsymbol{G}=\langle\boldsymbol{Y}, \boldsymbol{U}, \boldsymbol{P}\rangle-$ coherent and a-cyclic unigraph with a single initial node and a single final node which describes interdependence and permissible sequence of works execution, $\boldsymbol{Y}=\left\{y_{1}, \ldots, y_{i}, \ldots, y_{k}, \ldots, y_{m}\right\}-$ set of the nodes of the graph representing initial and final events for each works $u_{j}$ - node $y_{i}$ start and node $y_{k}$ completion of work $u_{j}$ execution; $\boldsymbol{U}=\left\{u_{1}, \ldots, u_{j}, \ldots, u_{l}, \ldots, u_{n}\right\}-$ set of arcs (arrows) of the graph representing relatively independent works (activities) which are constrained by initial $y_{i} \in \boldsymbol{Y}$ and final $y_{k} \in \boldsymbol{Y}$ nodes;

$\boldsymbol{P} \subset \boldsymbol{Y} \times \boldsymbol{U} \times \boldsymbol{Y},\left\langle y_{i}, u_{j}, y_{k}\right\rangle \in \boldsymbol{P}$ - three-term relation which assigns to each arc $u_{j} \in \boldsymbol{U}$ the initial $y_{i} \in \boldsymbol{Y}$ and final node $y_{k} \in \boldsymbol{Y}$;

$\boldsymbol{L}: \boldsymbol{U} \rightarrow \boldsymbol{R}^{+}$- function defined on the set $\boldsymbol{U}$ of arcs of the graph $\boldsymbol{G}$ which determines the certain $l_{j}$ or expected $E\left[L_{j}\right]$ values of the variables $L_{j}$ which describes the size of works $u_{j} \in \boldsymbol{U}$. 
The second, the construction technology model $£$, describes the type, attributes, capacity, and other requirements and restrictions of the resources which should be used to perform the works. On the basis of analysis of the model $\boldsymbol{S}$ and conditions of work $u_{j} \in \boldsymbol{U}$ execution, a set $\boldsymbol{H}$ of rational or optimal teams $\boldsymbol{H}^{r}$ is designed. Each team $\boldsymbol{H}^{r} \in \boldsymbol{H}$ should have the equipment which makes it possible to execute the works $u_{j} \in \boldsymbol{U}$ on schedule, within budget, safely, and above the owner/customer's quality demands. Finally, for the expected values $E\left[L_{j, r}\right]$, the teams $\boldsymbol{H}^{r} \in \boldsymbol{H}$ and the tasks $u_{j} \in \boldsymbol{U}^{r}$, expected values $E\left[K_{j, r}\right]$ and $E\left[T_{j, r}\right]$ are calculated. The basic requirements are then described as follows:

$$
\mathscr{E}=\{\langle\boldsymbol{H}, \boldsymbol{K}, \boldsymbol{T}\rangle, \boldsymbol{S}\}
$$

$\boldsymbol{H}=\left\{\boldsymbol{H}^{1}, \boldsymbol{H}^{2}, \ldots, \boldsymbol{H}^{r}, \ldots, \boldsymbol{H}^{s}\right\}-$ set of teams $\boldsymbol{H}^{r}$ rationally or optimally organized and well prepared for works $u_{j} \in \boldsymbol{U}^{r}$ execution,

$\boldsymbol{T}:(\boldsymbol{H} \times \boldsymbol{U}) \rightarrow \boldsymbol{R}^{+}$- function defined on the set $\boldsymbol{H}$ of teams $\boldsymbol{H}^{r}$ which, per the conditions of risk, determines the expected values $E\left[T_{j, r}\right]$ of random variables $T_{j, r}$ and describes the expected duration of the works $u_{j} \in \boldsymbol{U}^{r} \subset \boldsymbol{U}$.

$\boldsymbol{K}:(\boldsymbol{H} \times \boldsymbol{U}) \rightarrow\left\langle\boldsymbol{R}^{+}\right\rangle-$function defined on the set $\boldsymbol{H}$ of teams $\boldsymbol{H}^{r}$ which, per the conditions of risk, determines the expected values $E\left[K_{j, r}\right]$ of random variables $K_{j, r}$ and describes the expected cost of the works $u_{j} \in \boldsymbol{U}^{r} \subset \boldsymbol{U}$.

\section{IDENTIFICATION OF SMALL BRIDGE CONSTRUCTION IN RISK CONDITIONS}

In order to explain the method of construction risk identification, an example of small bridge construction has been described. Disruptions of the work have been evaluated on the basis of analysis of the weather circumstances, the soil-water conditions, the qualifications, experience, and discipline of employees, the operating reliability of machines and equipment, as well as defects of construction products and perturbation of the supply of materials. The changes of the cost of labor and performance of machinery and the prices of construction products have also been considered. Due to possible significant changes of random events and their influence on the course and results of the 
works, the favorable, moderate, and difficult conditions of bridge construction have been investigated. In the beginning, the complete list $\boldsymbol{U}^{e}$ of the technologically homogeneous work $u_{k}^{e}$ has been defined. The size $l_{k}^{e}$ or expected sizes $E\left[L_{k}^{e}\right]$ of work $u_{k}^{e} \in \boldsymbol{U}^{e}$ have been evaluated directly on the basis of design documentation. The interdependent works $u_{k}^{e} \in \boldsymbol{U}^{e}$ have been merged into the complex works $\boldsymbol{U}_{j}=\left\{\ldots, u_{k}^{e}, \ldots\right\}$ and the set $\boldsymbol{U}=\left\{\boldsymbol{U}_{1}, \boldsymbol{U}_{2}, \boldsymbol{U}_{3}, \boldsymbol{U}_{4}, \boldsymbol{U}_{5}, \boldsymbol{U}_{6}, \boldsymbol{U}_{7}, \boldsymbol{U}_{8}, \boldsymbol{U}_{9}\right\}$ of complex works has been defined (Figs. 1, 2; table 1, col. 2, 3). Each complex work $\boldsymbol{U}_{j}$ is related to the execution of a specific element, module, or subsystem of the bridge structure. Finally, based on the analysis of the structure and the complex works $\boldsymbol{U}_{j}$ and their permissible sequence $\boldsymbol{U} \in \boldsymbol{U}_{j}$, The design characteristics model of the bridge structure $\boldsymbol{S}=\langle\boldsymbol{G}, \boldsymbol{L}\rangle$ (Fig. 2; table 1, col. 3, 4, 5) has been developed. The bridge construction technology model $\mathscr{E}=\{\langle\boldsymbol{H}, \boldsymbol{K}, \boldsymbol{T}\rangle, \boldsymbol{S}\}$ has been developed on the basis of analysis of the resources which are needed for the execution of the project $\boldsymbol{U}_{j} \in \boldsymbol{U}$. Taking into account model $\boldsymbol{S}$, the type and technological interdependence of the tasks $\boldsymbol{U}_{j} \in \boldsymbol{U}$, working teams $\boldsymbol{H}^{r}$ and a set $\boldsymbol{H}=\left\{\boldsymbol{H}^{1}, \boldsymbol{H}^{2}, \boldsymbol{H}^{3}, \boldsymbol{H}^{4}, \boldsymbol{H}^{5}, \boldsymbol{H}^{6}, \boldsymbol{H}^{7}, \boldsymbol{H}^{8}\right\}$ of teams have been designed (Table 1, Col. 8). Each team $\boldsymbol{H}^{r}$, at any given moment $t$, can execute only one task $\boldsymbol{U}_{j} \in \boldsymbol{U}$, that is $\forall(t \wedge j):\left|\boldsymbol{U}_{j}^{r}(t)\right|=1$. Then, for the moderate conditions example, the values of the coefficients of optimism $\underline{p}_{j, r}^{t}$ and $\underline{p}_{j, r}^{k}$, and the coefficients of pessimism $\bar{p}_{j, r}^{t}$ and $\bar{p}_{j, r}^{k}$ have been estimated. Due to the short duration of the project and the stable economic conditions for that period, the coefficients of optimism and the coefficients of pessimism have been estimated as equal for the duration and cost of work, that is $\underline{p}_{j, r}^{t}=\underline{p}_{j, r}^{k}=\underline{p}=0,2$ and $\bar{p}_{j, r}^{t}=\bar{p}_{j, r}^{k}=\bar{p}=0,3$. Using these coefficients the values $\underline{T}_{j, r}, \bar{T}_{j, r} \underline{K}_{j, r}$ and $\bar{K}_{j, r}$ (Table 1, Col. 10, 12, 16, 18) the values $E\left[T_{j, r}\right.$ ] and $E\left[K_{j, r}\right]$ have been calculated (Table 1, Col. 9, 15). Next, the coefficients $\underline{p}_{j, r}^{p t}=\underline{p}_{j, r}^{p k}=\underline{p}^{p}=0,1$ of condition improvement, and the coefficients $\bar{p}_{j, r}^{n t}=\bar{p}_{j, r}^{n k}=\bar{p}^{n}=0,15$ of condition deterioration have been estimated. For these values of the coefficients and the values $\underline{T}_{j, r}^{p}, \underline{K}_{j, r}^{p}, \bar{T}_{j, r}^{p}, \bar{K}_{j, r}^{p}$, $\underline{T}_{j, r}^{n}, \underline{K}_{j, r}^{n}, \bar{T}_{j, r}^{n}$ and $\bar{K}_{j, r}^{n}$, the values $E\left[T_{j, r}^{p}\right], E\left[K_{j, r}^{p}\right] E\left[T_{j, r}^{n}\right]$ and $E\left[K_{j, r}^{n}\right]$, have been calculated (Table 1, Col. 13, 14, 19, 20). The models $\boldsymbol{S}$ and $£$ contain all data which is needed for construction risk evaluation (Table 1). The first stage of construction risk analysis is hereby completed. 

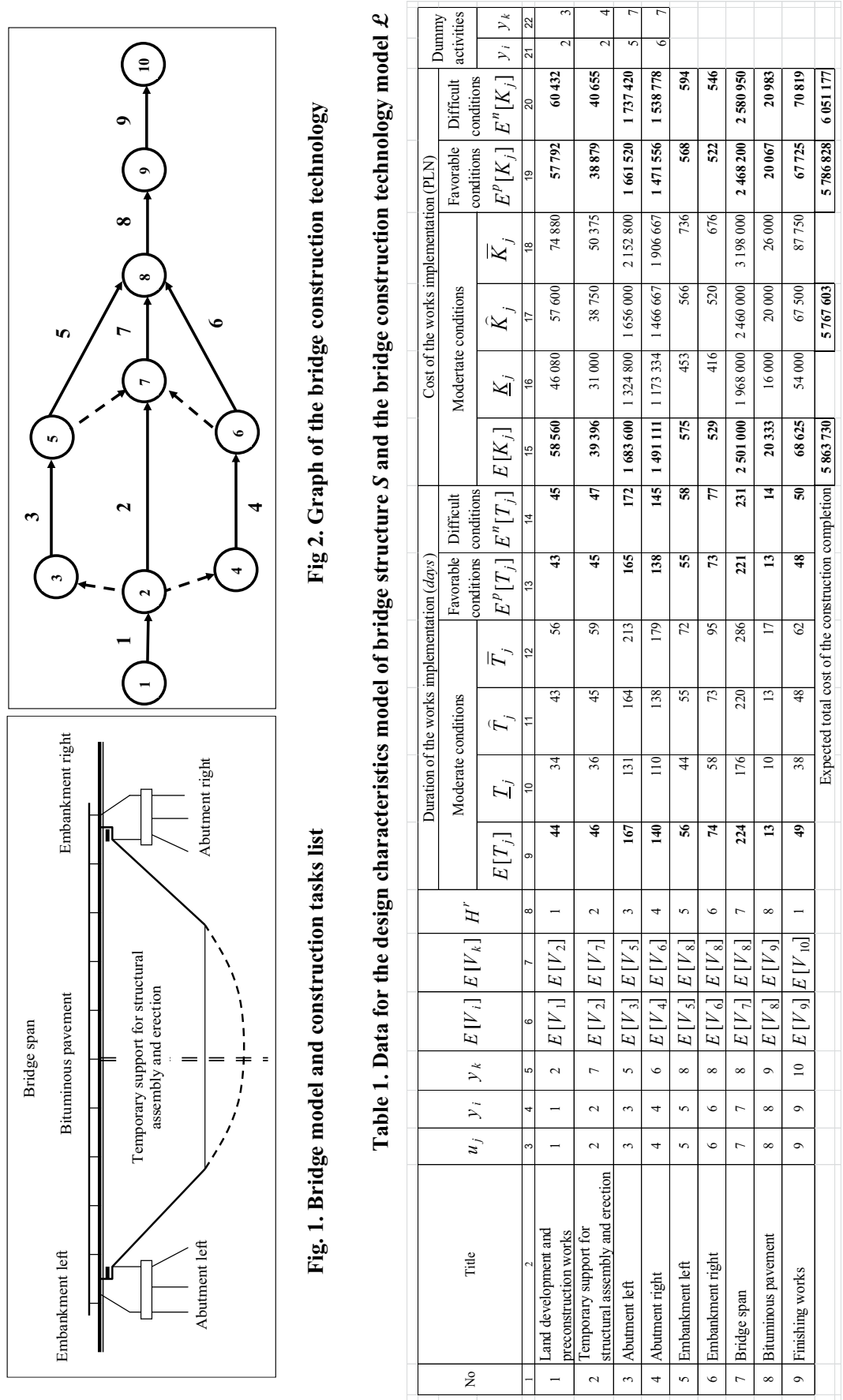


\section{Conclusions}

The method of construction risk identification described in the article has been worked out in order to prepare more reliable data for scheduling and pricing construction. In the method, in order to assure the high credibility of risk identification, proper estimates of the duration and cost of work are recognized as the most important, and the selected distribution of the durations and costs of the works as essentially insignificant $[2,3]$. This determines the method of identifying the duration and cost of work per the presented risk conditions. The realistic duration of each work is estimated on the basis of commonly used catalogs of standards of resource consumption and analysis of the probabilistic conditions of the construction. The realistic cost of each work is estimated on the basis of most commonly used price lists as well as the analysis of the probabilistic conditions the construction. this greatly simplifies the estimates of the data. There are also situations when the realistic values of the duration and cost of work must be estimated on the basis of individual analysis of technology, resources, and conditions influencing the implementation of all of the work. Then, according to the probabilistic conditions, and in accordance with the probability distribution of duration and costs, the remaining probabilistic parameters of the works are estimated. In effect, in the proposed approach, the PERT beta distribution of the duration and cost and their simplified computational formulas are used. This is an open approach, meaning that risk identification in accordance with this method enables application of different probability distributions. Finally, one can confirm that this method of construction risk identification assures a more realistic description of construction technology than the deterministic approach. 


\section{REFERENCES}

1. Batselier J., Vanhoucke M., Construction and evaluation framework for a real-life project database. International Journal of Project Management 33 (2015), 697-710.

2. Hajdu M., Effects of the application of activity calendars on the distribution of project duration in PERT networks. Automation in Construction (2013). http://dx.doi.org/10.1016/j.autcon.2013.05.025, Elsevier. AUTCON-01598.

3. Hajdu M., Bokor O., Sensitivity analysis in PERT networks: Does activity duration distribution matter? Automation in Construction 65 (2016). 1-8.

4. Konior J., Enterprise's risk assessment of complex construction projects. Archives of Civil Engineering. Vol. LXI, Issue 3, 2015. DOI: 10.1515/ace-2015-0025. 63-74.

5. Mubarak Saleh A., Construction Project Scheduling and Control. John Wiley \& Sons, 2015. ISBN: 978-1-11884600-1, pp. 504.

6. Skorupka D., Method of Construction Projects Risk Assessment. LAMBERT Academic Publishing GmbH \& Licensors, Saarbrücken 2012.

7. Skorupka D., Identification and initial risk assessment of construction projects in Poland. Journal of Management in Engineering, 2008. 120-127.

8. Z. Milian, Dokładne rozwiązania problem PERT z mieszanymi rozkładami czasu realizacji zadań. Czasopismo techniczne, z.2 Budownictwo z. 1-B, $2010 \mathrm{r}$.

9. A. Sobotka, P. Jasiak, Uwzględnienie ryzyka w ocenie czasu w ofercie rewitalizacji obiektu zabytkowego. Budownictwo i Inżynieria Środowiska; ISSN 2081-3271, 2011, vol. 2 no 4, 651 - 654.

\section{LIST OF FIGURES AND TABLES}

Fig. 1. Bridge model and construction tasks list

Fig 2. Network model of the bridge construction technology

Table 1. Data for the design characteristics model of bridge structure $\boldsymbol{S}$ and the bridge construction technology model $\mathfrak{L}$

\section{LISTA RYSUNKÓW TABEL}

Rys. 1. Model mostu i lista zadań budowlanych

Rys. 2. Model sieciowy technologii budowy mostu

Tablica 1. Dane modelu technologii konstrukcji mostu $\boldsymbol{S}$ i modelu technologii budowy mostu $\mathscr{L}$ 


\section{KWANTYTATYWNA IDENTYFIKACJA RYZYKA BUDOWY}

Słowa kluczowe: konstrukcja, budowa, modele, identyfikacja ryzyka budowy

\section{STRESZCZENIE:}

Kwantytatywna metoda identyfikacji ryzyka budowy, którą opisano w artykule, pozwala identyfikować probabilistyczne parametry i charakterystyki ryzyka robót budowlanych na placu budowy. Identyfikowany jest wpływ losowych czynników zakłócających przebieg i wyniki robót. Identyfikowane dane dotyczą ryzyka budowy i stanowią podstawę oceny ryzyka opóźnienia ostatecznego terminu i ryzyka wzrostu całkowitych kosztów zakończenia budowy. Zakłada się, że budowa może być realizowana tylko wtedy, gdy zakłócenia losowe nie uniemożliwiają realizacji budowy zgodnie z dokumentacją projektową i specyfikacją techniczną wykonania i odbioru robót. W tym sensie zakłócające czynniki losowe mogą jedynie opóźniać ostateczny termin i zwiększać całkowite koszty zakończenia budowy. W silnie niestabilnej sytuacji realizacyjnej powinny być identyfikowane pomyślne, przeciętne i niekorzystne warunki budowy.

Przeciętne warunki budowy mają miejsce, gdy zdarzenia losowe są typowe dla danego regionu i miejsca budowy, mają umiarkowany wpływ na czas trwania, koszty i jakość wykonania robót. W takiej sytuacji, na podstawie dokumentacji projektowej i analizy warunków realizacji, są szacowane wartości zmiennej losowej $L_{j}$ : racjonalnie najmniejsza (minimalna) $\underline{L}_{j}$, realistyczna (przeciętna) $\hat{L}_{j}$ i rozsądnie największa (maksymalna) $\bar{L}_{j}$. Wartość oczekiwaną $E\left[L_{j}\right]$ zakresu robót jest obliczana wg zależności $E\left[L_{j}\right]=\frac{\underline{L}_{j}+4 \widehat{L}_{j}+\bar{L}_{j}}{6}$. Podobnie są obliczane wartości zmiennych losowych $T_{j, r}$ i $K_{j, r}$. Wartości realistyczne $\widehat{T}_{j, r}$ oblicza się wg zależności $\widehat{T}_{j, r}=\widehat{L}_{j} \widehat{P}_{j, r}$. Wartość $\widehat{P}_{j, r}$, czyli pracochłonność roboty $u_{j} \in \boldsymbol{U}^{r} \subset \boldsymbol{U}$, gdy jest wykonywana przez brygadę $\boldsymbol{H}^{r} \in \boldsymbol{H}$, jest określana na podstawie katalogów nakładów rzeczowych. W wielu przypadkach odpowiada to rzeczywistości. Jeśli takie oszacowanie może być obarczone istotnym błędem wartości $\widehat{T}_{j, r}$ i $\widehat{P}_{j, r}$ powinny być szacowane bezpośrednio na podstawie indywidualnej analizy technologii, zasobów i warunków wykonania robót. Koszty realistyczne $\widehat{K}_{j, r}$ są obliczane wg zależności $\widehat{K}_{j, r}=\widehat{T}_{j, r} \hat{\mathrm{K}}_{j, r}^{t}$ lub $\widehat{K}_{j, r}=\widehat{L}_{j, r} \hat{\mathrm{K}}_{j, r}^{l}$. Zaś wartości optymistyczne $\underline{T}_{j, r}$ i $\underline{K}_{j, r}$ oraz pesymistyczne $\bar{T}_{j, r}$ i $\bar{K}_{j, r}$ wg zależności $\underline{T}_{j, r}=\widehat{T}_{j, r}-\underline{p}_{j, r}^{t} \hat{T}_{j, r}$ i $\underline{K}_{j, r}=\widehat{K}_{j, r}-\underline{p}_{j, r}^{k} \hat{K}_{j, r}$ oraz $\bar{T}_{j, r}=\widehat{T}_{j, r}+\bar{p}_{j, r}^{t} \widehat{T}_{j, r}$ i $\bar{K}_{j, r}=\widehat{K}_{j, r}+\bar{p}_{j, r}^{k} \widehat{K}_{j, r}$. Współczynniki optymizmu $\underline{p}_{j, r}^{t}$, które mogą być równe na przykład $[0,05,0,1,0,15,0,20]$, opisują możliwe skrócenie czasu trwania robót ze względu na słabsze oddziaływanie zdarzeń losowych na przebieg i wyniki robót. Współczynniki pesymizmu $\bar{p}_{j, r}^{t}$, które mogą być równe na przykład $[0,1,0,15,0,20,0,25]$, opisują możliwe wydłużenie czasu trwania robót ze względu na silniejsze oddziaływanie zdarzeń losowych. Współczynniki optymizmu $\underline{p}_{j, r}^{k}$ i pesymizmu $\bar{p}_{j, r}^{k}$ opisują możliwe zmniejszenie i zwiększenie koszów. Współczynniki te dodatkowo zależą od finansowych i ekonomicznych uwarunkowań rynku budowlanego. Wartości oczekiwane $E\left[T_{j, r}\right]$ i $E\left[K_{j, r}\right]$ oraz odchylenia standardowe $\sigma\left(T_{j, r}\right)$ 
i $\sigma\left(K_{j, r}\right) \quad$ są obliczane $\quad w g \quad$ zależności: $\quad E\left[T_{j, r}\right]=\frac{\underline{T}_{j, r}+4 \widehat{T}_{j, r}+\bar{T}_{j, r}}{6} \quad$ i $\quad E\left[K_{j, r}\right]=\frac{\underline{K}_{j, r}+4 \widehat{K}_{j, r}+\bar{K}_{j, r}}{6} \quad$ oraz $\sigma\left(T_{j, r}\right)=\frac{\bar{T}_{j, r}-\underline{T}_{j, r}}{6} \mathrm{i} \sigma\left(K_{j, r}\right)=\frac{\bar{K}_{j, r}-\underline{K}_{j, r}}{6}$.

Pomyślne warunki budowy mają miejsce, gdy nie wszystkie zdarzenia losowe przewidywane w warunkach przeciętnych mogą wystąpić lub, gdy mogą mieć słabszy wpływ na przebieg i wyniki robót. Są to najlepsze możliwe warunki budowy. Podobnie jak w warunkach przeciętnych szacowane są wartości optymistyczne, realistyczne i pesymistyczne czasu trwania i kosztów każdej roboty. Zakłada się, że wartości optymistyczne i realistyczne w warunkach pomyślnych, są równe wartościom, które oszacowano dla warunków przeciętnych, czyli $\widehat{T}_{j, r}^{p}=\widehat{T}_{j, r}, \widehat{K}_{j, r}^{p}=\widehat{K}_{j, r}$ oraz $\bar{T}_{j, r}^{p}=\bar{T}_{j, r}$ i $\bar{K}_{j, r}^{p}=\bar{K}_{j, r}$. Wartości optymistyczne są obliczane wg zależności $\underline{T}_{j, r}^{p}=\underline{T}_{j, r}-\underline{p}_{j, r}^{p t} \underline{T}_{j, r} \mathrm{i} \underline{K}_{j, r}^{p}=\underline{K}_{j, r}-\underline{p}_{j, r}^{p k} \underline{K}_{j, r}$. Współczynniki poprawy warunków $\underline{p}_{j, r}^{p t}$ i $\underline{p}_{j, r}^{p k}$ opisują prawdopodobną poprawę warunków budowy i możliwy w wyniku tego stopień skrócenia czasu trwania i zmniejszenia kosztów robót. Współczynniki $\underline{p}_{j, r}^{p k}$ dodatkowo zależą od uwarunkowań finansowych i ekonomicznych rynku budowlanego. Wartości oczekiwane obliczane są analogicznie jak w warunkach przeciętnych.

Warunki trudne budowy mają miejsce, gdy prawdopodobne jest istotne pogorszenie warunków budowy w porównaniu do warunków przeciętnych oraz wydłużenie czasu trwania i kosztów robót. Są to najgorsze możliwe warunki realizacji robót. Wartości optymistyczne i realistyczne zakłada się takie same jak w warunkach przeciętnych, czyli: $\underline{T}_{j, r}^{n}=\underline{T}_{j, r}$, $\underline{K}_{j, r}^{n}=\underline{K}_{j, r}, \hat{T}_{j, r}^{n}=\widehat{T}_{j, r}, \quad \hat{K}_{j, r}^{n}=\widehat{K}_{j, r}$. Wartości pesymistyczne są obliczane wg zależności $\bar{T}_{j, r}^{n}=\bar{T}_{j, r}+\bar{p}_{j, r}^{n t} \bar{T}_{j, r}$ i $\bar{K}_{j, r}^{n}=\bar{K}_{j, r}+\bar{p}_{j, r}^{n k} \bar{K}_{j, r}$. Współczynniki pogorszenia warunków realizacji $\bar{p}_{j, r}^{n t}$ and $\bar{p}_{j, r}^{n k}$ opisują prawdopodobne pogorszenie warunków budowy oraz możliwy w wyniku tego stopień wydłużenia czasu trwania i zwiększenia kosztów robót. Współczynniki $\bar{p}_{j, r}^{n k}$ mogą wymagać korekty dodatkowo ze względu na pogorszenie uwarunkowań finansowych i ekonomicznych rynku budowlanego. Wartości oczekiwane obliczane są analogicznie jak w warunkach przeciętnych. Warunki technologiczne konstrukcji obiektu są opisywane za pomocą modelu technologii konstrukcji $\boldsymbol{S}=\langle\boldsymbol{G}, \boldsymbol{L}\rangle$. W modelu tym graf $\boldsymbol{G}$ opisuje zbiór i współzależność technologiczną przedmiarowanych robót. Natomiast funkcja $\boldsymbol{L}$ opisuje rozmiar przedmiarowanych robót. Wielkości te określane są na podstawie analizy projektu budowlanego. Warunki technologiczne ze względu na wykonanie robót i wykorzystywane zasoby są opisywane za pomocą modelu technologii budowy $\mathscr{E}=\{\langle\boldsymbol{H}, \boldsymbol{K}, \boldsymbol{T}\rangle, \boldsymbol{S}\}$. Wartości funkcji $\boldsymbol{K}$ i $\boldsymbol{T}$ opisują odpowiednio koszty i czas realizacji robót $\boldsymbol{S}$ przez brygady robocze zbioru $\boldsymbol{H}$. Wartości tych funkcji są określane na podstawie analizy modeli $\boldsymbol{S}$ oraz dyspozycyjnych zasobów i warunków wykonania robót. Modele $S$ i $£$ zawierają wszystkie dane, które opisują ryzyko budowy w warunkach przeciętnych, pomyślnych i trudnych. Identyfikacja wpływu losowych czynników zakłócających na przebieg i wyniki robót stanowi pierwszy etap analizy ryzyka budowy. W drugim etapie analizy ryzyka dane te są wykorzystywane do opracowania kosztorysów i wyznaczenia harmonogramów budowy w analizowanych warunkach budowy. Następnie w etapie tym, zgodnie z opracowanymi kosztorysami i wyznaczonymi harmonogramami, jest obliczane ryzyko opóźnienia ostatecznego terminu zakończenia i wzrostu całkowitych kosztów budowy. 